DOI: 10.20472/IAC.2019.049.046

\title{
RONNIE YEARWOOD
}

University of the West Indies, Barbados

\section{RASHAD BRATHWAITE}

University of the West Indies, Barbados

\section{THE LEARNING STYLES OF LAW STUDENTS (AT A CARIBBEAN TERTIARY INSTITUTION)}

\begin{abstract}
:
The purpose of this research is to assess the learning styles of law students at the University of the West Indies, Cave Hill Law School in the Caribbean, using the Grasha-Riechmann survey. On the basis of the outcomes of the survey, a number of themes will be explored. Firstly, do law students (at the UWI, Cave Hill Campus) have different learning styles from other students at the UWI Cave Hill Campus? The basis of comparison will be a study of learning styles of UWI Cave Hill students (Corbin, 2017) which applied the Grasha-Riechmann survey. Secondly, having understood the learning styles of the law students through the survey, can it be argued as a policy position that the Law School should be encouraged to assess the learning styles of each incoming student year in order to align teaching methods for the better performance of law students. Thirdly, though understanding learning styles can be useful to improving student performance, it is critical to recognize that it can be misleading to teach according to the dominant learning styles. This critical insight is important for law students because lawyers as professionals need to be competent in all learning styles, so perhaps a better approach would be to teach to various learning styles across the entire Law School. Fourthly, the survey of the learning styles of the law students can be the start of a longitudinal study to assess whether the learning styles change over the life-time of their legal education.
\end{abstract}

\section{Keywords:}

Learning Styles, Caribbean Law, Legal Education 